Yeshiva University, Cardozo School of Law

LARC @ Cardozo Law

Articles

Faculty

1993

\title{
Gynaetopia: Feminine Genealogies of Common Law
}

Peter Goodrich

Benjamin N. Cardozo School of Law, goodrich@yu.edu

Follow this and additional works at: https://larc.cardozo.yu.edu/faculty-articles

Part of the Law Commons

\section{Recommended Citation}

Peter Goodrich, Gynaetopia: Feminine Genealogies of Common Law, 20 Journal of Law and Society 276 (1993).

Available at: https://larc.cardozo.yu.edu/faculty-articles/335

This Article is brought to you for free and open access by the Faculty at LARC @ Cardozo Law. It has been accepted for inclusion in Articles by an authorized administrator of LARC @ Cardozo Law. For more information, please contact larc@yu.edu. 


\section{Gynaetopia: \\ Feminine Genealogies of Common Law}

\section{PETER GOODRICH*}

In order to make an ethics of sexual difference possible, it is necessary to retrace the ties of feminine genealogies ... at the levels of law, religion, language, truth and wisdom ... [I]t is necessary to introduce into the history of reason an interpretation of the forgetting of feminine genealogies and thereby re-establish their economy. ${ }^{1}$

Criticisms of law and of the legal profession from feminine perspectives considerably pre-date the various phases of modern feminist movements. In many respects, lawyers were a privileged object of feminine critique while the law itself represented the essential reason, antagonism, and distance that characterized the masculine domination of the polity. The correspondence of women married to barristers of the Elizabethan Bar indicate that it was emotionally unfortunate and domestically undesirable to attach oneself to men of law. Lawyers, it was said, married for venal motives, namely money, social advancement, and political influence; they were married first and exclusively to their profession; they were mean-spirited, cavilling and much absent; the law consumed them and left them spent, deprived of civility, humour, and emotion. ${ }^{2}$ A slightly later tract, In Defence of the Female Sex, summarizes the failings of lawyers in terms of 'eager and disputative' men whose undoubted wit and judgement was expended in 'thwarting and opposing one another' to the effect that they became 'impatient, sour . . . morose' and incapable of conversation. The evidence explicitly offered for this observation was the training that lawyers received at the Inns of Court, where students led 'a recluse and monastic life, and converse little with our sex. They want neither wit nor learning . . . yet when they come into gay, though ingenious company, are either damped and silent or unseasonably frolicsome and free, so that they appear either dull or ridiculous'. ${ }^{3}$

It is not the purpose of this essay to rehearse directly the perennial and frequently barren terrain of the social incompetence, subjective estrangement or emotional ineptitude of lawyers. Such criticism is better read against a series

\section{* Corporation of London Professor of Law, Department of Law, Birkbeck College, University of London, Malet Street, London WC1E 7HX, England}

My thanks to Neil Duxbury, Les Moran, Marty Slaughter, Peter Rush, and Ronnie Warrington for comments on an earlier version of this article. Yifat Hachamovitch both commented and meticulously reduced this article to its final form. 
of constitutional texts which not only argued the political and legal preeminence of women but also suggested the possible presence of a feminine genealogy repressed within the ancient constitution. ${ }^{4}$ At a popular level, the misogyny of English law and the 'dissembling practice' of its lawyers were countered in terms of female courts, women's law and feminine justice. The anonymous theatrical polemic, Swetnam the Woman-Hater arraigned by Women, places the misogynist author of a tract published in 1615, entitled The Arraignment of Lewde, Idle, Froward and Unconstant Women, on trial before a specially constituted women's court presided over by a 'Ladie Chiefe Justice'. ${ }^{5}$ The sentence passed by this 'Female Court' upon the misogynist was (ironically) that he be silenced, that is, deprived of speech, and exiled. ${ }^{6}$ The pseudonymous Ester Sowernam responded to the same misogynist pamphlet by presenting a striking defence of women in the form of a genealogy of the feminine extracted from the Bible, mythology, and other ancient histories. She systematically listed the achievements of great women, the lineage of feminine rulers, and the virtues of the feminine exemplified by particular women rather than by any essential or homogeneous class character. ${ }^{7}$

The focus of the following essay will be on the popular invocation of feminine courts, female justices, and a separate and superior law originating from and administered by women under the feminine sign of fate or justice, fortune or phronesis. It will be argued that such texts form part of a largely forgotten tradition of constitutional writings which trace a feminine genealogy of common law, an origin and a telos of legal judgment, in a lost or future gynocratic polity. Such a genealogy traces the feminine within the constitution and commits itself to the dissipation of the palpably coercive unitary conception of common law:

a return to the origins of our culture reveals that it was once otherwise, that there was an epoch when it was the woman who initiated the rites of love. In that time, the woman was goddess and not servant, she guarded both the carnal and the spiritual dimensions of love. ${ }^{8}$

Prior to analysing three legal texts as evidence of this tradition, narrely, John Fortescue's De Natura Legis Naturae (1466), John Selden's Jani Anglorum Facies Altera (1610), and the anonymous Lawes Resolutions of Women's Rights (1632), ${ }^{9}$ a brief description of the classical background of this suppressed tradition is necessary.

\section{SOURCES OF LAW AND STATUSES OF WOMEN IN THE ANCIENT CONSTITUTION}

While it doubtless needs little emphasis, it is as well to begin by restating in some detail the diverse subordinate statuses of women within the various historical domains of common law. One dimension of such an analysis is the manner in which it illustrates forcefully the interdependence of the various laws governing the civil and ecclesiastical polity and still implicit, if frequently unrecognized, in contemporary law. At the level of structure or of what was 
termed 'universal law', the civil position of women was dictated by their inferiority, their subordinate and accessory place in opposition or accession to men. The first source, historically and conceptually, is invariably the Corpus Iuris, and there is little scope for feminist argument in the great Roman compilation. The Digest provides an extensive though scarcely coherent medley of prohibitions, incapacities, and denigrations of women as persons alieni iuris, subject to another's control. ${ }^{10}$ General statements of principle are to be found in D.1.9.1 (Ulpian), 'greater dignity inheres in the male sex', and in D.1.5.9. (Papinian), 'there are many points in our law in which the condition of females is inferior to that of males (detior est condicio feminarum quam masculorum)'. While it is not feasible to provide any comprehensive account of specific disabilities, the most obvious incapicities are comprehensively disabling. Most broadly, by D.50.17.2 (Ulpian):

women are debarted from all civil and public functions and therefore cannot be judges or hold a magistracy or bring a lawsuit or intervene on behalf of anyone else or act as procurators.

By D.16.1.1 it is reiterated that women, like children, cannot perform any civil functions, they cannot undertake obligations and, by D.16.2.5, women are prohibited from acting as anyone's defensor, concluding that 'a woman is not allowed to act in defence either of her husband, her son or her father.' The doctrinal logic underlying these and other incapacities stems from the obverse of women's inferior condition, namely the potestas or power of men. All authority in the family, including, in early Roman law, the power of life and death over children, lay with the male head of the family, the paterfamilias. The woman was, thus, either under the power of her own family or, after marriage cum manu, would become the daughter of her husband (filiae loco). Finally, if an adult woman became independent on the death of her father or husband, she was forced into tutelage, into having a tutor assigned. ${ }^{11} \mathrm{By}$ D.1.9.8 (Ulpian), husbands confer their dignity or status on their wives, while by the Institutes 1.11 .10 , 'women cannot adopt. They do not hold family authority even over their real children.'

The positioning of women in permanent guardianship reflects an astringent scholastic view of feminine capability. Sex and disability are cognate with femininity, and it is reiterated throughout the law that women cannot perform the functions of men. ${ }^{12}$ Weakness, vulnerability, cunning and deception, frivolity, frailty, and shamelessness were by the time of the early Renaissance forensic commonplaces to be expanded, on the one hand, by reference to divine law and, on the other, by returning to the earlier scholastic sources of the patristic tradition. With the probably apocryphal exception of the daughter of Accursius, who is said by John Leslie to have "professed the Civil law openly', ${ }^{13}$ neither the glossatorial nor the post-glossatorial tradition on the continent offered much by way of reform of the position of women. The strongly anti-feminist arguments of Jean Bodin's De Republica ${ }^{14}$ were influential in England and typical of humanist constitutional doctrine of the later reception. His refutation of gynocracy argued that it was 'absurd and inconvenient' ${ }^{15}$ for women to govern, to which he adds finally that France, by 
lucky virtue of the "law Salique cuts the mother short and expressly forbids that a woman should by any means succeed into any fee'. ${ }^{16}$

Bodin's reference to Salic law was made in the context of a work which also stated that English common law was simply a borrowing from French local law. François Hotman, in his influential Franco-Gallia, also asserted the primary role of the Salic exclusion of women but interestingly added a reference to Tacitus to the effect that in Britain there was 'no distinction of sexes in Government'. ${ }^{17}$ Hotman's general conclusion with regard to the state of French law stemmed from the civil law disability of women which was referred to 'their weakness of judgment'. In terms that would sound well in the language of common lawyers, Antoine Hotman authored a Traité de la Loy Salique, which argued that the exclusion of women in France depended upon antique custom, upon unwritten law, upon antiquity of the greatest weight and authority, 'as being of uncertain origin, more august and venerable for being collected out of inviolably guarded and uninterrupted usage. ${ }^{18}$ The exclusion could not be proved but could only be referred by conjecture to "the most ancient memory . . . et sunt haec arcana imperii [and these are the mysteries of government] which we would better reverence rather than research.' ${ }^{19}$ It remained to be argued that this immemorial French custom was of such age and validity as to be best considered as a part of nature "honouring France above all other nations in the world'. ${ }^{20}$

In ecclesiastical, civil, and local law, the ambiguous place of women as the vehicles of biological and cultural transmission whose sex nevertheless overwhelmingly excluded them de iure from participation in political office, institutional function or real property right, was clearly a significant issue. It was recognized that all human beings passed through the maternity and tutelage of the gynaecium and yet, despite this crucial place and pedagogy of the feminine, civil law continued to deny it any direct association with the polity or public sphere. The continental debate within legal doctrine indicated both that women were a significant constitutional problem and that lawyers could not ignore wider theological and literary debates as to the place of women. Within French literary culture, the tradition of advocacy of feminine causes dated back to Christine de Pisan's La Cité des Femmes, a gynaetopia descriptive of an imaginary city universally sheltering women. Written in 1404, The City of Ladies was translated into English in 1521 and joined a wider post-classical tradition of defences and laudatory works. ${ }^{21}$ While the praise of illustrious women belonged to a classical literature stemming from Plutarch's De Mulierum Virtutibus, orators, educationalists, and ecclesiastics of the Renaissance and the Reformation saw the place, personality, and political role of women as a topic of immediate and threatening proportions. It was precisely because women were politically suspect and legally of uncertain status within the newly vernacularized jurisdictions across Europe that the querelle des femmes, the formulaic debate as to the place, social and natural status, education, and deportment of women emerged in law. ${ }^{22}$

The immediate doctrinal background to Fortescue's De Natura is to be found in the various unsystematic rules relating to the diverse legal capacities 
and functions of women in Glanvill, Bracton, and Fleta. ${ }^{23}$ The source of the rules was fairly uniformly that of Roman law, and the variations occasioned by medieval forms of homage, lordship and kingship were consonant with the underlying structure of civil law. Thus, Glanvill states the law of English inheritance as being that:

if anyone has a son and heir and also a daughter or daughters, the son succeeds to everything ... the general rule [being] that a woman (mulier) never shares in an inheritance with a man. ${ }^{24}$

The most significant legal status of women was, of course, marriage and Glanvill states that 'legally a woman is completely in the power of her husband', a civilian rule which is elaborated in terms of the complete loss of the wife's power over any property, including present or future dower, with the sole partial exception of an inheritance acquired prior to marriage. All her property is otherwise deemed to be at the disposal of her husband for him 'to give, alienate or sell in whatever way he pleases ... and his wife is bound to consent to this as to all other acts of his which do not offend against God.'25 Glanvill further adopts Roman law in asserting that a married woman cannot make a will without her husband's consent, ${ }^{26}$ and subsequently states that if a woman or women are left as heirs of anyone they stay in ward of their lords and 'even if they are of full age ... they remain in ward (in custodia dominorum) until they are married on the Lord's advice and direction'. ${ }^{27}$

In Bracton, the first classification of persons, following Gaius, is between slave and free. ${ }^{28}$ The second division of persons is between male, female, and hermaphrodite, to which it is added that 'women [feminae] differ in many respects from men, for their position is inferior to that of men' ${ }^{29}$ Bracton is dependent upon Roman law in his depiction of women and is even more direct in asserting the inferiority of their status. Women are not simply in the power of others, in the wardship or tutelage of lords: 'some are under the rod (sub virga), as wives'. ${ }^{30}$ In terms of property, Bracton coins an appropriately circular legal maxim - 'everything that is the wife's is the husband's' - for the traditional reason that the wife does not have potestatem. ${ }^{31}$ While many of the more detailed rules relating to women, as that pertaining to women married to men attainted of felony or outlawed, have a local character, ${ }^{32}$ the more general and exhaustive account of marital status and the incapacities that result from the woman's loss of will, remain, and are acknowledged as civilian. So too Bracton recognizes certain of the forms of protection that the civil law offers women. Gifts made to concubines are to be recognized as valid and a concubine may enfeoff her children. Gifts between husband and wife are invalid for fear of duress or beguilement or improper cause (alias causas) such as lust. ${ }^{33}$ Nor may the husband commit fraud against 'the constitution of dower' by making gifts to strangers with a view to the stranger transferring the property to the wife during the husband's lifetime or after his death. ${ }^{34}$ While the common law is developed from the civil, it was not always politic to recollect that descent and, in consequence, the status of women in municipal law could at least on occasion be argued. ${ }^{35}$ The legal context of Fortescue's $D e$ Natura Legis Naturae, the earliest text to be encountered in the common law 
querelle des femmes, is undoubtedly that of Roman law and of continental custom. For all Fortescue's concern in De Laudibus Legum Angliae or in Governance of England to assert the historical priority and the national distinction of common law, both the method and the substantive content of those treatises are drawn closely from the European law. ${ }^{36}$ The context of the discussion is the law of succession and it is largely governed by civil and ecclesiastical rules. ${ }^{37}$

\section{OF FATE, FORTUNE, JUSTICE, AND OTHER ILLUSTRIOUS WOMEN}

In the context of a legal structure so markedly geared to the restraint of female right, it seems remarkable that there was space at all for the assertion of contrary argument. Deprived of access to public office and defined most usually by the 'civil death' (civiliter mortua) of marriage, namely, by the loss of will that accompanied the transfer of the daughter to the husband, the representation of feminine right was necessarily a polemical activity and closer in style to myth than to constitutional doctrine. The specific question debated in the two books of De Natura Legis Naturae is that of succession in supreme kingdoms:

A King, acknowledging no superior in things temporal, has a daughter and a brother. The King dies without sons. The question is whether the Kingdom . . . descends to the daughter, the daughter's son, or the brother. ${ }^{38}$

A variety of answers are available to this question. By some local English law, it was possible that the daughter inherit, the law of gavelkind allowing succession to sons and daughters equally. ${ }^{39}$ By Roman law, the inheritance would pass by the male line to the king's brother, while in ecclesiastical law, the same would hold with even more stringent prohibitions upon the possibility of feminine office.

What is surprising about Fortescue's De Natura is that it devotes an entire work of two books to the question of women. Taking the form of a dialogue and latterly, in the second book, of a mock trial, the issue initially is that of what law is to govern the debate. The resolution to this question is more complex than is immediately apparent. All vernacular law claims antique or immemorial status, as also it claims the benefaction of divine decree. Just as Antoine Hotman depicted Salic law as customary practice so old as to be the uncorrupted law of nature expressive of a pristine sacred will, ${ }^{40}$ so Fortescue depicts English custom as prior to and necesarily consonant with the divine law as well as the law of nature and nations. The question of which legal forum and which law is to decide the issue of feminine sovereignty raises questions of theology, nature, and positive law, of written and unwritten prescription, of regal and political dominion. No one law can resolve an issue as fundamental as that of the constitution and being of woman but, rather, one law must be folded into another according to the sacred hierarchy of normative orders, 'for the Civil Laws say that the offspring is a portion of the mother's entrails' ${ }^{41}$ 
The order of law begins with man's abandonment of original justice and state of grace. This means that the origin of law is unknowable: its past presence can no longer be recollected, it cannot be other than the immemorial and inconstant representation, simulacrum or vestigium of a pre-lapsarian state. It is termed divine providence, fate, law or will, and it is the mother of natural law: 'Law of Nature is daughter of Divine law'. ${ }^{42}$ This Christian amor matris or love of an ineffable mother, of incertitude as the feminine source of the descent of all law, is expressed more directly in the figure of justice herself. The maternal line which runs from divine law to natural law, the feminine thread upon which both laws precariously hang, is justice depicted first as truth: 'the truth of justice (iustitiae veritas), which is capable of being revealed by right reason', is the law of Nature. Secondly, however, the truth of justice is termed Phronesis 'and is comely of face and lovely of aspect'. ${ }^{43}$ The feminine face or decor of justice is no accident. ${ }^{44}$ In one genealogy of the iconography of justice, the fates are daughters of the Parcae who are in turn the daughters of necessity. Dike is similarly a feminine God. ${ }^{45}$ Fortescue provides a literal expression of this iconography or imagery in indicating at the beginning of the second book that 'justice is also a judge', she who assigns to everyone her right, for a judge is so named from pronouncing judgment 'and she pronounces judgment, since, as the laws say generally judgment is given by her; she is indeed herself the judge of all human actions' ${ }^{46}$

One possible interpretation of Fortescue's use of feminine imagery is simply to deny that it has any political or legal significance: it is, like rhetoric and like art or plastic representation, merely decorative or accidental. The femininity of justice is simply its materiality, its contingency and not its essence: it is as it is represented for the reason that its representation is no more than a reminder or ephemeral sign of its cause. Surprisingly, Fortescue argues directly to this effect:

Nor is it any obstacle to her power that women are by law excluded from the judicial office; for although the word justice be of the feminine gender, she herself is not a woman nor of the female sex; for sex hath no place in virtues any more than in spirits. ${ }^{47}$

While this statement might appear to deny the expression of any feminine cause or sentiment in the actual representation of judgment, it is nonetheless the case that the femininity of the image, of the material presence and person of positive law and of its insular forms does at least institute certain anomalies and suggest separate orders and genders of the common law. Like Janus, the common law has at least two faces. Like the widow's memory of her husband depicted in the Ladies Calling, legal retrospection multiplies the images of the past. ${ }^{48}$

The civil law dictates that the law (ius) takes its name from justice (justitia). This derivation of the name of law instructs the lawyer through a grammatical method which 'makes known to us some natures both of laws and other virtues by force of etymologies'. ${ }^{49}$ That ius takes its name from Justitia obliges Fortescue to conjecture that: 
from the same it hath derived the origin of its generation, and is thus entitled to be distinguished by the name of its parent ... but as the lustre from the light, the heat from the fire, the gushing stream from its spring, so doth the law of nature come from justice... justice begets law. ${ }^{\text {so }}$

The generation of natural law, of 'Dame Nature' as source of law, involves a complex principle of inner lineage, a principle of ruin or of relics. The femininity of justice is not only the representation of a material and so contingent form of judgment, justice is memory as reminiscence and as legitimacy, the memory of generation, of maternity, of the certitude of the only begetting to the only begotten. Justice survives in the temporal law by means of vestiges and similitudes. Justice is a temporal yet internal image (ymaginem) which triggers recollection of who we are by virtue of reminding us whence we came. The femininity of justice is the cunning of memory as reminiscence, as the mirror of the plurality of experience; it is the reason of likeness, the ultimate law which Fortescue admits can never produce a true image or pure visibility for:

of creatures there be no true likenesses whereby the creature may be truly assimilated to its Creator, no more than the shadow to the body, the footprint to the foot, or the image to the real thing, yet in all things some likeness is discovered to their creators. ${ }^{51}$

The paradox which confronts the common law - 'our Lady the common law' - is thus resident in the dual nature of the image and the two faces of justice. The image is both memory and the recollection or relic (footprint) of divine reason. It is the deceptive form of experience, the fragile symptom or sign of accident, and yet it is also the vehicle or bearer of essence, it is the footprint of God (Dei vestigia) and so, too, the only surviving sign of the generation of law. And justice itself is paradoxically a woman. It is not a woman in terms of Christian or natural law essence, because neither spirit nor soul have a sex; the truth is precisely the proper form of the incorporeal. Justice is as a woman because even the law has a body, and it is in bodies that sex exists (in corporibus est sexum). It is feminine because if it is a question of the application of law, a question of experience and judgement; of likenesses and their material inscriptions, then justice requires that the law acknowledge the ethical and contingent logic, the fluidity, of the event. Fortescue admits such contingency as one face of the common law but denies that such feminine attributes are ever anything other than secondary to the speculative logic of law. He admits the figure of woman as an accident in the development of common law and as a symbol that purveys a likeness of law but not its essence, which is God. To adopt even a very simplified psychoanalytic reading of Fortescue's denial of the significance of the female form of justice, it would have to be said that the denial, or, more properly, the negation, precisely confirms that the plural figure of woman is inseparable from that of law:

The general tenor of the argument pursued in the second book of De Natura is unremarkable. The King's daughter argues from divine law and specifically from the judgment of Moses in the case of the daughters of Zelophehad who were allowed to inherit the name and estates of their father. ${ }^{52}$ She further offers a summary genealogy of female rule, of noble and erudite women whose 
antiquity coincides with natural law'and whose role in the history of England constitutes a precedent: 'did the law which permitted so many women to reign ever exclude me therefrom?' 53 On the other side, it is argued that the law should distinguish the right of succession to kingdoms from the right of succession to private estates. Nature subjects the female sex (muliebri sexui) to the male in both social and domestic circumstance, while the civil law reflects this subjection by excluding women from public office. More than that, the querelle is invoked to specify, with unnecessary or at least non-probative detail, female characteristics of simplicity, subservience, physical inferiority, lesser virtue, deformity, irrationality, slenderness of understanding, lack of heat, deficiency of construction, heedlessness, timidity, fear of death, and the proclivity to domesticity (yconomia). ${ }^{54}$

The replications and the duplications conform, in detail and in range of argument, to the broader querelle des femmes. What is exceptional is the scope of legal sources drawn upon to substantiate the disassociation of the feminine imagery and grammatical gender of nature, justice, virtue, and law, from the dignity or public or civil office of women. Standard arguments from the name (virago is a diminutive of vir); from creation (man was created first); from original sin (Eve was first tempted); and divine judgement (God sentenced Eve to bring forth children in sorrow, and to be in the power of her husband) are all adduced to support the morality of both laws, civil and canon, in relation to women. The only further point that bears brief description is that from the notion of 'ymago Dei'. It is man who is made in the image of God and after his likeness, for the Bible states: 'faciamus hominem ad ymaginem et similitudinem nostram.' The canon law reiterates that woman was not made in the image of God and adds that 'the woman veils her head, because she is not the image of God. ${ }^{55}$ It would be against fate, against the nature of things and 'contrary to the principle of Being (non esse de ratione entis) ${ }^{\prime 6}$ to grant women the right of succession. Both laws encapsulate and formulate as rules the previously existing and divinely ordained disability of women.

The duplication of the daughter reverses the assumptions of the replications. It is the form of the querelle to contradict in polemical fashion and the daughter does not disappoint. Suffice it to relate that her argument hinges on a history or antiquity which is older than that presented by the male litigants. If divine judgment punished feminine sin by subordinating women to their husbands, then logically and historically, women were orginally - and so by nature and inclination - free of subordination. In the law of Nature, the male argument is void: subjugation was a penalty and not a property of feminine being. Secondly, subordination was the sentence of married women only. It would be profane and against all principles of penal law to extend the punishment to unmarried women. ${ }^{57}$

The judgment itself is taken directly from patristic texts, specifically from Augustine's Civitate Dei, and asserts an ordained or providential ontological order in which the original disposition of priorities or prelacies favoured the male and subordinated the female sex. The woman ought to be subject to the man, 'as the flesh to the spirit ... the pre-eminence of the man over the woman 
seems to be [comparable] to the pre-eminence of the reasoning faculties over sensual appetites, or of the soul over the body'. ${ }^{58}$ Neither history nor counterexample nor evidence of feminine virtue could in any way transmute or by length of time prescribe a woman's right to office. The inferiority of women within the hierarchy of 'proper nature' was a facet of the originary, of the state of innocence, and so an incontestable law of nature coincident with the spirit which preceded the generation of the sexes. What is established as a principle of being or asserted as providence or fate is not amenable to change any more than immemorial custom, practice time-out-of-mind or any other of the 'rubbish of antiquity' could fall either by reason or by desuetude from the common law.

\section{JANUS OR THE OTHER FACE OF ENGLISH LAW}

The immediate subsequent history of the question of feminine status at common law tended to revolve around specific issues and did not directly rely upon any genuine re-opening of the querelle des femmes. The place of women was mapped and the Janus face of common law was turned elsewhere. What is surprising is that the place of women is raised as an issue at all, let alone that subsequent constitutional texts should advocate their independence. Thus, for John Perkins, A Profitable Book Treating of the Lawes of England, first published in 1532, women are not a legal category but rather a series of statuses spelled out in relation to specific property rights and transactions. Thus, the married woman is compared to the monk, friar, servant or canon as one without right and incapable of either livery or seisin. ${ }^{59} \mathrm{~A}$ grant made by a feme covert during the absence of her husband, "notwithstanding the husband were abroad or out of the country, wandering at the time of such grant ... so that it was not known whether he were alive or dead, yet such grant is void if he be living. ${ }^{\prime}{ }^{\circ}$ Nor can the wife make a testament in the absence or without the consent of the husband. The rules may be multiplied and, on occasion, Courts of Equity would recognize certain rights in the wife who would be treated for such purposes under the fiction that she were a feme sole, for example, with respect to property granted specifically for her separate use or with regard to certain devices used by the husband to enfeoff the wife. ${ }^{61}$ In conceptual terms, Sir Thomas Smith in the influential De Republica Anglorum simply reasserts the Aristotelian limitations upon the role of women and adds by way of flourish that the civil law on the issue of succession should govern in England, 'on which consideration also we do reject women'. ${ }^{62}$ Yet, neither in Rastell's The Exposicions of the Termes of the Lawes of Englande, nor for that matter in Cowell's The Interpreter, is woman - either mulier or feme or foemina - an entry in its own right. ${ }^{63}$ It is tempting to think that as suddenly as it appeared at common law, the category of women would seem to have disappeared in the literature of abridgments, formbooks, entries, breviaries, and rolls that made as yet no attempt at systematic or conceptual classification. Women, however, remained a problem at a conceptual and constitutional level. 
Confusion of orders and genders is, in many respects, the signal theme of Jani Anglorum Facies Altera, ${ }^{64}$ a work which is explicitly dedicated to 'the Reverse or Back Face of the English Janus', ${ }^{65}$ which means the stories, fictions, and legends of common law, 'which I offer up in sacrifice ... these scraps and fragments of collection, relating entirely, what they are, and as far as the present age may be supposed to be concerned in ancient stories and customs'. ${ }^{66}$ The two faces (facieque biformi) of English law, 'for thou canst hardly choose but own him having two faces', ${ }^{67}$ are variously British and Norman, pre- and post-conquest, native and foreign, saturnine and mercurial, antique and contemporary, before and behind, and, finally, both male and female. It is a law which is marked, in other words, like Janus, by ambiguity and a certain indistinction. Where Janus was the god of doors and gates and presided over the beginning or origin of things, the Janus of English law similarly guarded the origin or entry into law, the indistinct, pre-institutional, and indefinite time of customary or unwritten law. Its history, Selden argues, is not only two-faced but also marred by neglect, by lack of regard and 'the injury of time' such that its past and its records are as close to myth as to historical narrative. From the remains of record and history, Selden endeavours to describe the legal constitution of 'Pananglium, that is, All England', ${ }^{68}$ a realm that in one view, that of Marcianus, has in it thirty three nations. ${ }^{69}$ And behind the legends of origin and of source of common law, behind the narratives of its diverse temporal beginnings, the representation or image of common law, its symbolic descent, is consistently portrayed as being from a variety of feminine images and female figures, the forgotten faces of a law which was never one.

The metaphor of prosographia, used by Fortescue and others, of a feminine face of justice returns most forcefully in Selden. To represent the backface or underside of the constitution, the institutional unconscious, myth or image, leads to a return to the legal querelle des femmes. It leads in particular to a tabulation of famous or illustrious women legislators, lawgivers, and sovereigns from antiquity to contemporaneity. In the time of the laws, old heroes went by the names of gods and in the druidical Celtic colony of Britain, the semnaitheia or 'venerable Goddesses' ruled. These were the goddesses of justice, the Furies, 'also called Themis', who sat 'upon the skirts of the wicked' and; as (by antiphrasis) the Eumenides, rewarded the good and 'such as are blameless and faultless'. ${ }^{70}$ They are the first judges of the Celtic common law, the deis matribus or mother goddesses to whom altars were inscribed and before whose dreadful justice the populace would tremble and shake. To this description Selden adds: 'Nor let it be any hindrance, that so splendid and so manly a name is taken from the weaker sex, to wit, the Goddesses. ${ }^{71}$ It is in honour of these goddesses of the night that the terms of the law and, indeed, the divisions of the calendar - 'the spaces or intervals of all time' - are defined not by the number of days, but that of nights. ${ }^{72}$

As to the historical face of the common law, it was frequently female. While Selden admits a certain 'poetick licence and rhetorical figure' to the preRoman stories, his own account, which starts with the druids, the severe and 
melancholic figures reported by Caesar, Strabo, and Tacitus, is even more explicitly feministic. Taking the side of Tacitus, who reported that the Germanic tribes held their women in almost mystical awe, Selden savages the anti-feminine sentiments of Bodin, of the Salic lawyers, and of Aristotle himself. Women in Britain participated in councils of war and in military duties, indeed 'Britons were want to war under the conduct of women, and to make no difference of sexes in places of government and command'. ${ }^{73}$ In one aspect, the argument is specific to Britain and to the regency of English queens, particularly those most illustrious of monarchs, Boadicea and Elizabeth. Women monarchs had often been the most successful and as Serjeant Lodowick Lloyd, in an equally feministic passage, argued slightly earlier, 'if men govern like women, then women should govern'. ${ }^{74}$

Selden's view was both that women had governed and that they should govern. In terms of the various pasts which Selden depicts, all are witness to feminine rule. In mythology there were 'more She-Gods than He-Gods', while 'virtue herself . . . is female in dress (cultu) and in name'. ${ }^{75}$ Indeed, Selden states that 'I will not declaim female excellency here: the thing speaks for itself more than I can, and the subject is its own best orator'. What follows this rhetorical gesture is a denunciation of Bodin's De Republica and an even more polemical assertion that Aristotle would admit women to government 'whatever the foolish interpreters of the Politics say'. ${ }^{76}$ Such an argument is a commonplace drawn fairly directly from the antinomic or polarized form of the querelle des femmes. ${ }^{77}$ There can be no natural law prohibiting women from government because historical counter-examples indicate that male rule, far from being universal and unchanging, is quite frequently the historical exception. Against Bodin, Selden thus lists the instances of matriarchy at the level both of cultures - such as Egypt - and at that of individual monarchs such as Deborah or Artemis. ${ }^{78}$ At an ontological level, he aligns women to the other face of reason, to the virtues of 'sanctity and foresight', on the strength of which the arguments against women can only be taken for 'mad rude expressions ... not unfit for a professor in Bedlam College ... Virtue shuts no door against anybody, any sex, but freely admits all' ${ }^{79}$

In one aspect, Selden's argument is that femininity is the other face of law, which he links directly to mythology, to fragmentary records, to a feminine imaginary and its figures of virtue. Elsewhere, in a study of the genealogy of the gods, Selden depicts the plastic symbolism of justice in terms of a lefthanded goddess; blind and beautiful, pure and untouched: she was nature in culture, wisdom in law: ${ }^{80}$ The metaphor (prosopopoeia) of another face of law may indeed be taken in many different senses. By analogy with Janus, the female face of law is the face that looks back, that remembers both the historical succession of feminine rulers but also, and more profoundly, the experience or generation of habits and customs. To understand custom one must look at law, but that law is never simply one. The law of custom is 'other' to law or, more accurately, it is an other law in that it is in and through custom that laws are 'discovered' or 'found' or 'declared' or otherwise born. Femininity would here be the hidden face of tradition and women would be 
both the custodians of the unwritten and the symbols of its transmission. Here, in the iconography of justice, Iustitia would be blindfolded so as to indicate that she looked with the eyes of the heart.

In another sense, the foresight which Selden attributes to femininity is a sign of the transcendental quality of legality itself. Foresight is connotative also of soothsaying and divining, of the powers of the divine which belong either within or without the law dependent upon the tasks or the purposes to which these powers are put. ${ }^{81}$ In a book on witchcraft addressed to Sir Edward Coke and published in the same year as Jani Anglorum, the theologian William Perkins ascribes an extraordinary power and materiality to the feminine principle at work in witchcraft. For Perkins, the power of the feminine is evident in the reality of their creations:

that witches may and do work wonders, is evidently proved ... and the wonders wrought by them are not properly and simply miracles, but works of wonder, because they exceed the ordinary powers and capacity of men, especially such as are ignorant of Satan's hability, and the hidden causes in nature, whereby things are brought to pass. ${ }^{82}$

The works of the feminine witch are not damnable for being unreal - 'they were works truly done and effected' - but for being unfaithful, immoral or in the service of other laws. Works of wonder, of divination and soothsaying, are deceitful only by virtue of the "evil end and purpose in working them, which is to lie unto men' as to the hidden nature of their causes. ${ }^{83} \mathrm{~A}$ law which borrowed substantially from the Anglican conception of a dual polity could not avoid at least confronting the power of such feminine reason, either so as to confirm or so as to banish its art and practice. For, in the end, the principle of reason upon which law was founded was neither male nor female. It has a sex only in its embodiment, in its materialization, in the intuition, discrimination, memory or choice through which it becomes law for us. The reason of judgment, of the application of law, is deemed the law of the second Venus, the copulation of norm and fact, general and particular, rule and circumstance. ${ }^{84}$

\section{WOMEN'S LAW}

In concluding his argument as to the right of women to govern, Selden stated 'nor could I forbear out of conscience with my suffrage, to assist as far as I could, that sex, which is so great and comfortable an importance to mankind'. ${ }^{85}$ Here and elsewhere in Jani Anglorum Selden had challenged aspects of the Renaissance interpretation of Aristotle and in this regard he builds upon a political tradition that saw Elizabeth's sovereignty as an occasion to reassert the argument for feminine office and rule. John Case, in the Sphaera Civitatis (1588) had attacked the assumption that the domestic duties and subjugation of women should be interpreted as extending to the public sphere:

Experience makes her wise. What, therefore, prevents women from playing a full part in public affairs? If one is born free, why should she obey? If one is heiress to a kingdom, why should she not reign? ${ }^{86}$ 
At one level this argument simply recognizes female regency as historical reality and suggests that constitutional doctrine recognize this accomplished fact. More interesting, however, than the political assertion of a challenge to scholasticism is the desire to develop and interpret this argument on the strength not of the classics but of common law. Thus, in debating the more complex issue of Mary Queen of Scots, it is John Knox, attacking the 'monstriferous empire', the enormity, vanity, odour, and 'pestiferous policies' of this idol, this 'cursed Jezebel', who relies wholly upon Roman law and patristic interpretations. ${ }^{87}$ The apologists for women turn to the vernacular English jurisdiction and the maternal common law.

Bishop Aylmer's response to Knox argues:

\begin{abstract}
that this matter belongs not to the civil law, but to the municipal law of England, for like as every field brings forth not all fruits: so is not one law mete for all countries. I grant that the civil law is the best, the perfectest and the largest, that ever was made: yet comprehends it not all things in all countries ... wherefore in appointing us to be ordered by civil law you offend in iustitia distributiva . . . our law must direct us, because it best agrees with our country. ${ }^{88}$
\end{abstract}

Civil law would smother England and extinguish those customary rules that were the distinctive inheritance of common law, its ancient stories which 'be the witness of time, the candle of truth, the life of memory ... and the register of antiquity'. ${ }^{89}$ The civil law, in its universality and abstraction, in its size and its strength, would destroy the feminine virtues of the local and particular experience of common law. Like a woman, the common law is inessential and particular when compared to its parent or its continental competitor; it has either to mimic the stronger and prior law or differentiate itself by defining itself against it. But whichever is the case, the memory of the rule of the parent civil law is traumatic for a common law which seeks its own identity through separation and polemic. For Aylmer, it is thus our 'own weights' that should weigh in the scales of justice and by those measures women are to be more liberally treated and their right to succession and office allowed.

Even more striking for its assertion of the vernacular law is the work of John Leslie in defence of Mary Queen of Scots' claim to the English Crown. Neither civil law nor Salic law have any place in England where the law is unwritten and 'grounded onlie upon a common and generall custome throughe owte the whole realme . . . as apperethe by the treatise of the aunciente and famous writter upon the lawes of the realme named Ranulphus de Glanvilla.'90 Leslie's account of the law ostensibly builds upon a detailed knowledge of uniquely English rules. The question of succession, concerning as it does the royal prerogative and powers, must be decided by rules that uniquely govern the sovereign. To this effect, he cites the 'maxime of lawe' that 'no maxime or rule in the lawe can extende to binde the kinge or crowne, unless the same be speciallie mentioned therein'. ${ }^{91}$ On the strength of this principle of interpretation, Leslie admonishes those who had taken legislation of 1350, An Act Touching such as be born beyond the Seas, as applying to the Crown, which was not specifically named. The legislation was taken, though only by implication, to deny the right of inheritance in England to those who were born out of 
England, out of the 'ligeance of the King' and whose parents were not 'of the obedience of the Kinge of Englande'. ${ }^{92}$ To apply such law to the Crown not only ignored the principles of statutory interpretation but also ignored constitutional history and the law on strangers recollected from English case law whose records no longer survive.

The distinction and idiosyncracy of English law is a theme common to Aylmer and to Leslie. It is thus argued comprehensively that 'by custom in England all manner of ... jurisdictions and other prerogatives [are], and ought to be, as fully and wholly and absolutely in the Prince female as in the male, and so was it ever deemed, judged and accepted'. ${ }^{93}$ It is upon the particular character and quality of such arguments that attention should be focused. Subsequent texts which argue for female rights or simply attempt to protect or defend the status or the interests of women are most striking where they attach such concern to substantive legal issues. On the one hand, there are texts such as Heale, An Apologie for Women (1609), which endeavour to argue for change in the law on the basis of theological and moral prescriptions. The sole topic of the Apologie is the question whether the husband has a legal right to beat his wife: In analysing the civil law - which governs all aspects of spousals and marriage - Heale finds many rules that are archaic, ignorant or simply morally objectionable. The catalogue of laws in need of reform includes the dependence of the wife on the husband in terms of dignity (she takes his name and status) and the duty of the wife to follow the husband from city to city or even abroad. It includes the 'strict and obdurate' rule that the wife loses her dowry for giving a 'lascivious kiss' and equally remarks the inequality that allows the husband to commit adultery but holds that if the wife 'play the Adulteresse ... the husband may then produce her into publike judgment, deprive her of her promised dowrie and expose her to perpetual divorcement'. ${ }^{94}$ Nowhere, however, in civil or canon law can Heale find any 'positive sentence or verdict that it is lawful for a husband to beat his wife'. ${ }^{95}$ It is pure interpretation based upon the invective of 'mysogynaes' and 'cynickes' who have either the hate or the ignorance necessary to bend the law and to suggest that so indecorous, immoral, and ill-mannered a custom could possibly be English law. If it is, however, to be taken as law, then there is nothing to say that the wife is legally bound to endure or tolerate such beating. She may leave her husband and the husband must pay her an adequate maintenance during her absence. ${ }^{96}$

Heale argues by extensive analogy and by reason of consistency. While his work certainly has its share of arguments drawn from the querelle - he praises famous women, he adopts the theological argument that Eve was made of man, but man was made of earth ('man by a strange kind of metamorphosis [was] converted into woman'97) - but the primary force of the argument is pragmatic and legalistic and does not go further than suggesting that male and female are equal in their qualities as in their failings. It is, for Heale, ultimately a constitutional question and so a question of manners, decency, and decorum in the estate of husband and wife. As decorum is the end or goal of the Anglican commonwealth, it is the task of the lawyer: 
as a laborious traveller [to go] through all estates, to bring all unto decency. He ordereth the estate of monarchs and princes; of peers and nobles; of magistrates and subjects; of parents and children; of husbands and wives; of masters and servants ... so that an absolute indecorum is an absolute breach of the law. ${ }^{98}$

Such a view may well seem to come close to the heart of the unwritten tradition: what is against the judicial perception of good manners or is 'not without vice' is unlawful of itself as being contra bonos mores, indelicate, odd or extreme.

The evidence of the Repertorium Canonicum and other abridgments and treatises would seem to suggest that in some areas doctrine does change to the end of greater protection of the separate rights of women. The rights or interests protected vary over time and are normally attendant upon or secondary to male interests. Nonetheless, fictions are developed to allow the husband to endow the wife; ${ }^{99}$ the issue of duress in marriage is canvassed in relation to gifts and wills made by the wife either to the husband or to strangers to the marriage; ${ }^{100}$ the wife is allowed a plea of non est factum in relation to debts; ${ }^{101}$ the interest of the unmarried woman in her own reputation is protected rigorously by laws of defamation; ${ }^{102}$ there is legislation on rape and the carrying away of unmarried women with property; ${ }^{103}$ the law governing separation and rights of alimony is further elaborated, ${ }^{104}$ as are other rules designed to maintain the reputation and decorum of the feminine. Decorum, however, while it may be the oldest of legal criteria is hardly the most definite nor necessarily the most accessible.

The greatest legal monument of the querelle is not Heale's defence nor Selden's poetic histories but, rather, a legal manual in the style of a work of self-help called The Lawes Resolutions of Women's Rights, anonymously published in $1632 .{ }^{105}$ While the popularization of legal knowledge was a dimension of the vernacularization which accompanied print, and many law dictionaries, books of precedents, and treatises were prefaced with remarks to the effect that every subject of the realm could now know the law, ${ }^{106}$ a book devoted to women's law and subtitled the Woman's Lawyer is a remarkable event. What could 'woman's law' be if the law knew no such category? The answer is that, for the purposes of this new legal discipline, the author of the Woman's Lawyer replaces the first division of the law of persons - that between slave and free - with a 'a primary distribution' between masculine and feminine, for masculum et foeminam fecit eos. ${ }^{107}$ Yet the category of woman includes no single designation or definition but rather lists every transaction in which femininity - the various categories of feme, mulier, foemina, dowager, concubine, virgin or ward - was an element.

The purpose of the treatise is twofold. It is first designed simply to extract from common law sources - from statutes, conjoining customs, cases, opinions, sayings, arguments, judgments, and points of learning - that part of English law 'belonging to women', or which 'contains the immunities, advantages, interests and duties of women'. ${ }^{108}$ In this respect, the work is ostensibly addressed generically to the illusory referent 'women' and is designed to provide information 'with as little tediousness as I can' ${ }^{109}$ which 
was not otherwise readily available. In this sense, the work is an exhaustive catalogue of points of law that mention, touch or affect the different categories, statuses or faces of the feminine. Such popular intent, however, has deeper roots, for as Selden found in Jani Anglorum, it is not possible to write a constitutional history, let alone list the laws that govern a majority of legal subjects without becoming aware of the ambiguity or the ethical inconsistency of the tradition. To compile an extended account of the law touching women was to produce a document enfolded in several jurisdictions or laws and of itself a record of peculiar cultural and political significance. The constant theme of the advice offered throughout the treatise was that of the defence of women, the critique of common law, and the manipulation of hostile rules to the benefit of an oppressed class.

Wherever the law could be ameliorated or its application tempered by foresight of feminine need, then the Woman's Lawyer offered the means of such fiction or improvement. Heale's example of the lawful right of the husband to beat his wife is confirmed, according to our author, by Brooke's Abridgement, which states that 'if a man beat an outlaw, a traitor, a pagan, his villein, or his wife it is dispunishable, because by the law common these persons can have no action.' 110 The reason at law for this disability is both specific, in the form of the precedent cited, and a consequence of the general status of the wife as sub potestate viri, and so without independent legal personality for most though not all purposes. There is thus no obvious legal solution to the problems of the woman whose husband is violent, either in precedent or in doctrine. The Woman's Lawyer, however, does not limit itself to remarking the woman's bad choice of company. A writ listed by Fitzherbert is cited which states that:

she may sue out of Chancery to compell him to find surety of honest behaviour toward her, and that he shall neither do nor procure to be done to her (marke I pray you) any bodily damage, otherwise than appertains to the office of husband or lawful and reasonable correction. ${ }^{111}$

The English Janus gave with one hand what it took away with the other. The Woman's Lawyer remarks that the scope of this power of correction is uncertain yet continues to observe that:

the sex feminine is at no very great disadvantage ... why may not the wife beat the husband ... what action can he have if she do ... the actionless woman beaten by her husband, hath retaliation left to beat him again, if she dares. ${ }^{112}$

The discussion of 'lawfulness' is concluded by remarking that if the husband come to Chancery to compel surety he is unlikely to be heard. While this may well have been good law, it is hard to imagine that it was good or feasible practice in a legal context in which a wife who killed her husband was guilty of the felony of treason, albeit petty treason against the prerogative of the husband. ${ }^{113}$

The advice offered in the above example would appear to be in part ironic, yet the fact that every section of the work contains similar advice for the woman suggests that in that instance it was more likely despair than flippancy 
that motivated the sentence. In other segments of the treatise the advice is of obvious purport and the suggestion of fictions would genuinely change the law. Different transactions, relationships, and threats create different problems for the female 'persona' in law and the Woman's Lawyer attempts no one solution or form of exchange for distinctive situations. Thus, one chapter of the treatise is devoted to the law on loss of dower, the wife's entitlement in law should the husband die before her: 'the rest of the fourth book shall consist most in warnings to widows and women tenants in particular estates, that they do nothing prejudicial to their warrant', namely to the writ of quod ei deforciat which allows a widow to recover dower. ${ }^{114}$ The subsequent chapter lists the various ways in which a widow might lose dower, as by allowing buildings or woods to fall to waste and so threatening the interest of the reversioner; if she alienated or made a gift of lands held in dower, the heir could recover. In broader terms, the advice on dower is not only cautionary but hortative. The Woman's Lawyer remarks that divorce and widowhood should in many respects be welcomed: 'Why mourn you so? Consider how long you have been in subjection under the predominance of parents, of your husbands, now you be free in liberty, and free proprii iuris at your own law' and under the power or 'controlment' of no man. ${ }^{115}$

In respect of other transactions, the woman may or may not retain legal personality according to specific rules. In some instances, the advice is trivial or humorous. The widow who takes more apparel than is convenient for her degree is made an executrix de son tort demesne, which is 'a troublesome office'. ${ }^{116} \mathrm{~A}$ wife only becomes entitled to dower upon consummation of the marriage and so is advised to leave the wedding party early 'and leave out the long measurles till you be in bed ... . get you there quickly, and pay the minstrels tomorrow. ${ }^{117}$ More serious advice pertains to the presumption of duress in relation to contracts between husband and wife, the possibility of employing fictions to enfeoff the wife, and the circumstances under which the crimes of the husband will be visited upon the wife, as when she loses her dower if her husband is outlawed or attainted of felony. ${ }^{118}$ The status of the married woman is that of infant: she loses her property, is incapable of making contracts, cannot sue or bring a writ in her own right and can neither inherit by nor make a will. At the same time, 'in matters of criminal and capital causes, a feme covert shall answer without her husband' unless the crime was committed with the husband or by coercion of the husband, in which case the wife cannot be charged. ${ }^{119}$

The disabilities and incapacities as well as the rights of women are specific to occasions and transactions. The Woman's Lawyer attempts to situate particular legal relations with regard to their impact upon the female sex. The closest that the work comes to a general account or critique of the law governing women is in relation to the inequality of legal provision in circumstances where difference of sex - however defined - would not appear determinative. Thus the law governing elopement, whereby a woman forfeits her dower for adultery but the husband is immune, and is allowed any number of adulterous relationships without forfeiture of land. Redress for this 
inequality should be 'by Parliament' and in the meantime there was the Christian solace of knowing that 'liberty or impunity in doing evil by immodest life or lascivious gallops, is no freedom or happiness'. ${ }^{120}$ In suggesting reforms of the law or in berating aspects of specific legal conditions such as the loss of noble status in a woman who marries below her degree, it is not so much the unity 'woman' as the fragmentary condition which is the object of critique. The feminine sex of legal subjects should not be 'abstruded', smothered, concealed or 'scattered in corners of an uncouth language', but, at the same time, the Woman's Lawyer does not treat that sex in an undifferentiated way. ${ }^{121}$ Thus, to take one final example, the Woman's Lawyer begins not by defining the classification of all persons into male or female, but, rather, by listing the seven ages that the woman has for legal purposes. The different legal states of femininity, as maiden, wife, widow, are cross-cut by virginity and maternity, but also by age, as, for example: 'woman is out of ward for her body [that is, she can marry] before she is out of ward for her land'. ${ }^{122}$ If she marries a man under age she remains in her father's ward. She may have dower at the age of nine, at twelve she may consent to marriage, at fourteen she may choose a guardian. ${ }^{123}$

\section{GYNAETOPIA OR THE LEGAL PLACE OF THE FEMININE}

The most strikingly contemporary feature of the Woman's Lawyer and, more generally, of feminine genealogies of law is the uncertainty of the category of women within early legal thought. In Selden's terms, the feminine was both the other face and the particularity of common law. At one level, this ambiguity forced law to mix with other literatures and to search the languages of theology, nature, philosophy, medicine, politics, ethics, and the other occult sciences to find some way of characterizing an essentially inessential being. The feminine, however, escaped delimitation: it was both fecund and fluid, both image and flesh, ignorant and erudite, illustrious and idolatrous, both Iustitia and Jezebel, matter and wonder. This sex which was not one, which was lost or 'clean abstruded' in the law was never successfully defined in advance as the querelle des femmes would have intended. Women were not a predicate of law but rather impermanent subjects of legal judgment. A woman was an expression of a legal event, of decisions and discretions made legible by the conflation of legal experience and imaginary literary sentiments. Indeed, literature here came to play the law and, to the extent that it embraced the literary representation of femininity, it did so at times to the benefit of women: it was through figures, presumptions, fictions, and dreams, through the imaginary, the other, the aesthetic, through a certain novel écriture as well as ethical argument that legal change occurred.

Fortescue and Selden derive what may properly be described as an image of woman from a lost genealogy or historical memory of femininity. It is also, in terms of its representation, under the sign of Polyhimnia, ${ }^{124}$ the femininity of memory as reminiscence, whereby 'out $\infty$ of one thing remembered others are 
discovered'. ${ }^{125}$ Jani Anglorum maps the places of women in the repressed, neglected or forgotten history of common law. It is possible that this narrative of the feminine in common law, of custody or custom as creativity and of tradition as generation, is to some large degree linked to the literary recollection of women, to gynaetopia and its illustrious women. In the City of Ladies it is after all Justice - defined as measure - who comes to the dreamer in 1404 and offers to people the City, the feminine commonwealth, with women of reason, prerogative, and honour. ${ }^{126}$ Justice is the third Lady but the chief virtue, and she represents a juridical history of illustrious women. In the ensuing tradition, it is not only the task of literary femininism to chart the narrative of feminine excellence and erudition; ${ }^{127}$ it also states the constitutional case for the right and sovereignty of women in the varied spheres of their political experience. In such terms Agrippa, for example, remarks that 'the English nation were most ungrateful, should they ever forget their obligations to this sex', or allow 'unjust laws, foolish customs, and an ill-mode of education' to continue to usurp their liberties. ${ }^{128}$ For Agrippa, to continue with the same example, women's proximity to generation and reproduction granted them an ontological superiority as well as a mythological sovereignty, for:

woman was formed miraculously . . . [and] was the end, and last work of God, and introduced into the world, not unlike a Queen into a royal palace ... Man seemed only her harbinger or attendant. ${ }^{129}$

The feminine was here the telos of nature, just as for Selden Iustitia, a woman, was the telos of law. ${ }^{130}$

At one level, it might be argued that this concern with justice as feminine, as an image and end of law, simply spells out in hyperbolic manner the formulaic commonplaces of feminist and anti-feminist rhetorics. ${ }^{131}$ In this sense, feminist argument, its exaggeration, speculation, and apocryphal histories, would simply represent the externality of the feminine to the legal: the image which is chosen to represent the system of law, the legal totality, would necessarily come from outside it. ${ }^{132}$ In Fortescue's terms, the likeness of law is not the law itself and there, perhaps, is one reason why in Renaissance iconography the face of justice was blindfolded, self-consciously following a classical tradition of mutilated representations of virtue in which justice would not see the face of the litigants nor they the face of Iustitia. ${ }^{133}$ If, as contemporary philosophy suggests, 'the face is presence' and command, and so neither metaphor nor figure, a feminine representation which is blindfolded would thereby be disallowed full presence, just as a woman could not command, except by way of exception. ${ }^{134}$ Yet the argument made is that where law sought to be blind, the feminine face of justice looked back so as to see. To consider further the significance of the face to law, it is necessary to return to the querelle and to contemporary rhetorics of gesture. In generic terms:

by the outward countenance we do judge of the qualities and disposition ... the most pliable part of virtue, is by greatest observance planted in the most proportionate feature. ${ }^{135}$ 
The outward face is the 'judgment of nature', for vultus est index animi, the countenance and the eye are the sign of the soul. Yet as Fortescue and Selden made clear, the face is not without its ambiguities; it was neither infallible as an index nor permanent as a sign of inward disposition. ${ }^{136}$

The face is also sexed. The shamefacedness of women was designed to protect men from themselves and to protect them from sin. The blindfold on the face of justice seems plausibly to have also benefited men through the limitation, mutilation - it could also be a bandage - or sensory deprivation of women. The stake of such an effigy, shadow or image is never innocent. In a secondary sense, the blindness of justice can be taken to represent the peculiar folly of common law in its dependence upon the blind reason of precedent and the unseeing eye of an aural or auricular tradition. In common with other critiques of common law, particularly that contemporaneously associated with the English civilians, ${ }^{137}$ the argument would be that without some vision of the peculiarities of parties and the particularities of circumstance and experience, the law has no connection with reality but simply and stupidly repeats past judgments as if they were both reason and law. Such repetition of judgment stipulates the present instance as a predicate of the past instance, without reason, foresight or ethics. The Woman's Lawyer challenged that predication and in constructing the law as it related to the various aspects of women, suggested that it is through the specific character, experience, and reason of judgment, through what the ancients termed synderesis, ${ }^{138}$ that legal personality is formed and the plurality of faces of women are distributed through the institutions and relations that constitute the social world for us.

Finally, if such baroque retrospection multiplies our images of woman at law, it does so perhaps by holding to her face a broken mirror - the very emblem of distortive retrospection. But it would be wrong to suppose that the truth of history is not also the effect of accident or crisis, that the many faces of the common law itself do not reflect its ambiguous relation to its past. The common law had no single identity: its polity was plurality and its history Janus-faced. In breaking away from Rome and the civilian tradition, the common lawyers were forced to invent a unitary national law, to find a representation which would bind together its disparate legal practices. The solution, in the form of an image, was that of a local and particular tradition of precedent, based upon a law that was lesbia regula or pliable rule, ${ }^{139}$ drawing upon the infinite uses of experience and a custom conceived as connatural to the people. ${ }^{140}$ To represent the separate and local features of the common law required the most misogynist of doctrinal writers to emphasize the distinctive and particular character of common law in terms of what would both then and now be perceived as feminine characteristics. The crises of the national law forced it to abandon the paternal regulae or rules of Rome, to represent instead the fecundity, the antique douceur of common law, to show the second face of the English Janus, namely, that of women: either Fate or Justice, Fortune, Nature, Prudence or Phronesis as occasion might demand.

The emblem of the feminine or, at least, the attribution of female characteristics allowed the reassertion or even the apparent rescue of common 
law from the harsh or, at least, foreign imposition of the civilian tradition. Humanism consistently argued by reference to the 'great Ladie of Learning ... true Philologie' and through her referred to even earlier, older or more pristine textual sources. ${ }^{141}$ It was implicit in the philological form of humanistic argument both that the most ancient source was the true source but also that time and diligence would constantly uncover new antiquities. In short, just as common law was shown to precede Roman law, so other insular laws were shown to antedate the common law. Prior to Edward the Confessor's unification of the kingdoms of Albion into one common law, the philologist could discover several other laws, the regencies both of feminine monarchs and before them of venerable goddesses. The priority of antiquity forced the possibility of feminine governance upon the common law, if only as its other face or exceptional past. These were the stories, the feminine genealogies of the greatest antiquity, of an original age of women: 'that is truth which is first, that is adulterous which comes after'. ${ }^{142}$ It is not surprising in this context that certain common lawyers even went so far as to suggest the recognition of feminine difference in the positive form of political suffrage, and civil and domestic rights. Insofar as elements of common law changed, it is not incorrect to say that legal events altered the 'relative or civil' definitions of women. ${ }^{143}$ It is also plain that such civil definitions of feminine status were relative to male governance and relative further to the loss or repression of the feminine genealogies which renaissance lawyers had briefly recollected. To understand that failure, loss or forgetting of a specific history and its texts, it is necessary to return again to the question of difference.

\section{CONCLUSION: THE JURISPRUDENCE OF DIFFERENCE}

The simultaneous praise and denigration or assimilation of the feminine is traditionally played out over a series of ambiguous and often antagonistic metaphors. Women, in the theological language which underpinned the ecclesiastical law, were images, surfaces or screens that lacked substance and depth. The feminine was empty and dissimulated or hid its emptiness through 'sophistic reasoning and carnal pretence'. ${ }^{144}$ More than that, the feminine transgressed the orders of nature and, like the plastic image, polluted the spirit by confusing it with sense. In one respect, this reference to sense was a mark of the contingency under which the feminine travelled. Contingency implied both the realm of the inessential, of the aesthetic, the floral, ${ }^{145}$ the inconstant, the gustatory, ornamental, and emotive, but also, by virtue of the particularity of the contingent, the feminine had symbolized justice, the law of the event and of the parties to dispute. In this latter aspect, the feminine was a sign of contingencia or touch, of a materiality, historicity, locality or relation which theology and ecclesiatical law often labelled unclean or polluted, of sense and flesh and earthly pleasure (erato). ${ }^{146}$ The belief that 'the feminine power prevailed in Heaven' was even listed in the Repertorium Canonicum as the heresy of the Sethiani. ${ }^{147}$ 
Women, by having no fixed value, by virtue of their uncertainty and ephemerality as also by virtue of their worldliness or reproductive force, were a threat not simply to the temporal order of political sovereignty but also to the logic of common law. This had inherited both Roman and ecclesiastical conceptions of universalia and with them, the notion of lawful meaning as a transcendent or spiritual property of eternal decrees and the reign of a reason that moved from like to like within the inexorable realm of the same. ${ }^{148}$ The belief in contingent values and in the arbitrary temporal power of fortune and fate, were pre-Christian elements of a Stoic philosophy which natural law had specifically replaced. 'Experience', in the words of one influential lawyer 'which is wholly gained by the observation of particular things is slow, blind, doubtful, and deceivable, and truly called the mistress of fools'. ${ }^{149}$ This mistress has an ambivalent and charged position in common law. As Fortescue had earlier remarked it was experience - induction - which "by the assistance of the senses and the memory' discovered law. ${ }^{150}$ It was the vernacular experience of the leges terrae which the common law judges had to apply and which differentiated common law from civil law, England from Rome. ${ }^{151}$ The common law had to assert a certain femininity, a reliance at least upon the mistress of experience, to identify itself as a separate form of law. Common law was like a woman but likeness was not essence, similarity was not identity and so experience remained a medium but not a source of law. To experience, which is characterized doctrinally as a feminine vice and opposed to the speculations, regulae, and maxims ${ }^{152}$ of the universal law, might be added contingency and materiality as such. The vice of femininity was precisely its nature, its plurality, both its diversity and its ability to reproduce, both its inconstancy over time and its production of difference. ${ }^{153}$ As one study has recently detailed, the category of the feminine in law was not simply plural but its attributes would change with time and historical circumstance. The virtues of the feminine might later be the attributes of the masculine, the value of contingency might latterly be the criterion of reason or the source of law, for nothing was certain in the realm of experience nor was anything constant where a feminine reason threatened to play the role of law. ${ }^{154}$

The argument traced through the texts suggests that there was no singular category of woman and as Sir Robert Filmer argued of the law in a rather different context, 'there is great difficulty in discovering, what or who a [woman] is' ${ }^{155}$ The plurality of concepts and usages of 'woman' range from the female as an image or, worse, an idol in puritanical legal thought, the bearer of diabolical powers, soothsayer and magician, to the praise of illustrious women, female gods, muses and lawmakers whose soul and reason are indistinguishable from or superior to that of men. ${ }^{156}$ There is no common essence to the various categories of women nor, indeed, is there any common definition of women in law. ${ }^{157}$ The 'feme sole' may share certain attributes of the married woman or 'feme covert'. The concubine may be granted certain aspects of the legal recognition of the wife. Unmarried women may in certain respects resemble the dowager lady. But the differences between statuses, 
between having a will and the civil death of marriage, between being sui iuris and alieni iuris, namely, between being in the potestas or power of the husband, or of the father and having independent status at common law, between the figure of women as indigni in the ecclesiastical law of succession, the detior conditio of civil law and the exclusion of women from office in Salic law, are too great to allow for the construction of any single concept of the feminine. For the purposes of the ecclesiastical law on witchcraft, it should be noted, finally, that even the civil law test of gender, as adopted by Bracton from the Digest ${ }^{158}$ to distinguish the sex of the hermaphrodite, was inapplicable in that it was precisely the power of the witch to work wonders (mirum), to deceive the eye and so to appear in the form of the dead or the masculine or animals that constituted both an office and a proof of being a witch. ${ }^{159}$

The latter example indicates both the power and threat constituted by femininity and its difference. To recollect the texts of feminine genealogies is to recollect an order of difference, a separate terrain and time of feminine kinship and regency approximating in myth or historical narrative to early law. In terms of legal history, the speech or mythology of female deities and women lawgivers had the status either of fabulous (and idolatrous) tales or, in Heywood's words, they were 'a fantasme, or an apprehension of an imaginarie thing' whose essence could not lawfully be sought. ${ }^{160}$ The negative connotations of difference linked the mythology of feminine genealogies to inconsequence or to heresy within the normative gaze of a common law that owed much to its ecclesiastical derivations. Under the category of difference were listed all the figures of exclusion, while the place of feminine difference was aligned with the gynaeceum, with the private, with the infantile, with impermanence and fantasy. ${ }^{161}$ It remains to be argued that returning, as this paper has endeavoured, to the mythologies of femininity in the ancient customs of common law may yet prove to be an important resource for feminist critiques of common law.

For early feminine critiques of law, the difference of the feminine was a powerful argument for a separate and positive status and law for women. The City of Ladies proposed a literal gynaetopia, a castle (fortuna) or a community of virtuous women kept separate from the world of men so as to pursue their virtue and their talents, to read, to learn, and to educate in female commonality free from the demands and the degradations imposed by the medieval world. In A Serious Proposal to the Ladies, Mary Astell later makes a similar suggestion. The proposal was to establish institutions for women, similar to religious houses, in which women could retreat from the world to a discipline, education, community, and charity of their own. The purpose of this gynaetopia was also political. It aimed to 'amend the present and improve the future age'. ${ }^{162}$ The regime of the community was again to be scholarly and studious: it would endeavour through learning to expel the "cloud of ignorance which custom has involved us in ... that the souls of women may no longer be the only unadorned and neglected things'. ${ }^{163}$ The proposal thus aimed to establish the value and the worth of women, to promote a philosophy of the 
feminine as well as a society dedicated to the furtherance of the education of its own sex. The regime of this collectivity was to reflect a society 'whose soul is love' and whose kinship was friendship. ${ }^{164}$ In a practical and political manner, the proposals of gynaetopias suggest a species of return to what Irigaray terms the forgotten feminine genealogies or 'to certain ancient but very advanced traditions in which it was the women who inititiated the men into love' and into the relationships and subjectivities, the politics and the civilities of eros. ${ }^{165}$

In a series of recent texts, contemporary feminists have suggested a return to the politics of difference. At one level the argument has been that it is essential to recognize and give space both to feminine difference and to the differences within the feminine. Thus, legal feminists have taken up the cause of a right to subjectivity, to care, and to relationship which emerged from a psychological study of the 'different voice' of the feminine. ${ }^{166}$ In a more sophisticated vein, feminist jurisprudence has asserted the need to allow a rhetoric or writing of the feminine, a speech authentic to feminine differences and so also a series of rights and legal protections for the sphere, space, time or speech of femininity. ${ }^{167}$ Utilizing the much frequented Sophoclean tragedy of Antigone, an argument is made for an 'other' law of the feminine which respects both nature and spirit, ecology and divinity, 'for in that time of feminine legal right, civil order was tied to respect for the gods and the civil and religious powers were not yet dissociated. ${ }^{168}$ The recourse to tragedy, to the dramatic representation of myth, is in effect a recourse to a series of political demands for respect for and guarantees of difference. In place of the demand for equality or for the legal right to be the same, Irigaray, for example, argues for an urgent and simple series of juridical reforms designed to establish a sphere of objective legal protections for feminine difference, namely, for a separate legally protected identity and full civic personality for the feminine and for the plurality which the feminine represents. The domains of sexually engendered identities and rights would reconstitute the law of persons according to a primary difference, that of sex:

Out of fidelity to sexual liberation and to the changes in the political horizon which it provoked, and further to permit a cultural cohabitation between the sexes, it is necessary to endow both women and men with rights corresponding to their respective needs. ${ }^{169}$

The legal right to difference, to a juridically protected sphere of autonomous feminine differences, would require a considerable re-writing both of law and of legal method. In an immediate sense, the right to a separate legally guaranteed civil identity ranges from protection of the physical, moral, and imagistic personalities of women, to genuine maternity rights free of economic, ideological (conjugal) or insititutional constraints, and a right to a culture, to languages, religions, arts, and sciences appropriate to the autonomy of feminine identities. ${ }^{170}$ In a broader sense, it is argued that civil law needs to be reformed so as to take account of the participation of two autonomous persons, two sexes, two genres, in love as also in the other relations of private and public life. ${ }^{171}$ Essential to this transformation is a recognition of rights of speech, a recognition of the other as an irreducible 
source of meaning, a recognition which would entail a certain respect for the mythologies, the languages, the figures, and the fictions of feminine genealogies. What is disclosed in this move to a jurisprudence of difference is the direct significance of law in the reconstruction of sexual ethics. It is the curious dialectic of this essay to suggest that the identity of the feminine and the 'objective rights and laws' which are to guarantee its autonomy are also the sites of the disappearance of any singular identity or unitary essence of the feminine. What is left, at least in theory, is the right and speech of women identified with a lineage or genealogy of law and of meaning transmitted from mother to child as well as from father to son. In this context the forgotten history of feminine genealogies and of various gynaetopias can offer a juridical narrative of the feminine genre and a language of difference as a practical sign of reciprocal right. Without embarking upon details of legal substance, the model of one law faced by or in juxtaposition with another is one of the oldest and most interesting of the histories of common law. One law on the other was the history of utrumque ius, the relation of the ecclesiastical to the 'profane' jurisdictions and of the spiritual to the secular laws. At various points in the history of the relation between jurisdictions, the same civil transaction, for example, would be tried before both spiritual and secular courts, either pro laesione fidei or upon a temporal contract, and would be decided according to two separate laws, according to faith and corporal penance, and according to profane law and its monetary compensations. ${ }^{172}$ There is no reason, either in history or in doctrine, why different laws cannot govern different genres, separate statuses or the plural identities of legal persons.

\section{NOTES AND REFERENCES}

1 L. Irigaray, 'Le Mystère Oublié des Généalogies Féminines' in L. Irigaray, Le Temps de la Différence (1989) at 120-21.

2 W. Prest, The Rise of the Barristers. A Social History of the English Bar 1590-1640 (1986) 115-26. For a comparable study of the lower branch of the profession, see C. Brooks, Pettyfoggers and Vipers of the Commonwealth. The Lower Branch of the Legal Profession in Early Modern England (1986) 132-51.

3 Judith Drake, An Essay in Defence of the Female Sex (1696, London: Roper) 140-1. See, also, Mary Astell, $A$ Serious Proposal to the Ladies for the Advancement of their True and Greatest Interest (1694/1696 ed., London: R. Wilkin).

4 The term ancient constitution is taken from J.G.A. Pocock, The Ancient Constitution and the Feudal Law (1987). Its reference is a particular sense of history, a belief in the 'indefinite past' and equally mystical present of common law. See, further, P. Goodrich, 'Poor Illiterate Reason: History, Nationalism and Common Law' (1992) 1 Social and Legal Studies 7.

5 Anon., Swetnam the Woman-Hater Arraigned by Women (1620, London: Meighen). J. Swetnam, The Arraignment of lewde, idle, froward, and unconstant Women (1615, London: T. Archer). For commentary, see Joan Kelly, Women, History and Theory (1984); Denise Riley, Am I that Name? Feminism and the Category of 'Women' in History (1988); Ian Maclean, Woman Triumphant: Feminism in French Literature 1610-1652 (1977); M.A. Case, 'From the Mirror of Reason to the Measure of Justice' (1993) 5 Yale J. of Law and the Humanities 115.

6 Anon., id., at sig. $\mathrm{K} \mathrm{i} \mathrm{b}$. The irony is simply that silence was, in theological terms at least, the duty or fate of women, as explicated, for example, in G. Fox, The Woman Learning in Silence or, the Mysterie of the Woman's Subjection to her Husband (1655, London: T. Simmonds). 
7 Ester Sowernam, Ester hath hang'd Haman: or an answere to a lewd Pamphlet (1617, London: N. Bourne). Also of interest are Rachel Speght, A Mouzell for Melastomus . . . or an apologeticall answere to that pamphlet made by J. Swetnam (1617, London: T. Archer); Constantia Munda (pseud.), The Worming of a Mad Dogge: or, a soppe for Cerberus the Iaylor of Hell (1617, London: L. Hayes).

8 L. Irigaray, J'Aime à Toi (1992) at 210. In a secondary though related sense, a genealogical form of historical narrative is one committed to the study of the plural and dispersed roots of identity: 'if genealogy in its own right gives rise to questions concerning our native land, native language, or the laws that govern us, its intention is to reveal the heterogeneous systems which, masked by the self, inhibit the formation of any form of identity'. M. Foucault, Language, Counter-Memory, Practice (1977) at 162. See, also, L. Irigaray, Marine Lover of Friedrich Nietzsche (1991).

9 Respectively, John Fortescue, De Natura Legis Naturae (1466) in The Works of Sir John Fortescue, ed. C. Fortescue (1869, London: private circulation); John Selden, Jani Anglorum Facies Altera (1610, 1683 ed., London: Basset); Anon., Lawes Resolutions of Women's Rights, or the Lawes Provision for Woemen (1632, London: J. More).

10 Curiously, the most extensive discussion of the civil law on women is to be found in J. Knox, The First Blast of the Trumpet Against the Monstrous Regiment of Women $(1588,1985$ ed.) at 44-8. For a general outline of the Roman law relating to women, see Jane Gardner, Women in Roman Law and Society (1986), and O. Robinson, 'The Historical Background' in The Legal Relevance of Gender, eds. S. McLean and N. Burrows (1988). With regard to the Renaissance reception of this law, see the excellent Ian Maclean, The Renaissance Notion of Women (1980) ch. 5. For a broader discussion and invaluable bibliographic guidance, see Maclean, op. cit., n. 5. Most recently, see Y. Thomas, 'The Division of Sexes in Roman Law' in A History of Women, ed. P.S. Pantel (1992) vol. 1.

11 See Digest 15.1.1.2-3 (Ulpian); D. 23.3.24 (Pomponius); D. 15.1.27 (Gaius).

12 See, for example, Digest 3.1.5 (De Postulando).

$13 \mathrm{~J}$. Leslie, A Defence of the Honour of the Right Highe, Mightye and Noble Princesse Marie Queene of Scotlande and Dowager of France (1569, London: E. Dicaeophile) at fol. 139a.

14 J. Bodin, De Republica, translated as The Six Books of the Commonweale (1580, 1606 ed., London: Knollers).

15 id., at 753.

16 id. The law states: 'de terra vero sallica nullo portio haereditatis mulieri veniat; sed ad virilem sexum tota terra haereditas perveneat (no portion of the land of France shall be inherited by a woman; but all the inheritance of that land shall come unto the male sex)'.

17 F. Hotman, Franco-Gallia or, an Account of the Ancient Free State of France (1574, 1711 ed., London: Goodwin) at 115.

18 A. Hotman, Traité de la Loy Salique in Opuscules Francoises des Hotmans (1616, Paris: M. Guilleme) at 267.

19 id., at 268.

20 id., at 269.

21 Christine de Pisan, The Boke of the Citye of Ladys (1521, London: H. Pepwell). This work is well discussed in J. Kelley, Women, History and Theory (1984). Particularly influential in Britain were Juan Luis Vives, De Institutione Foeminae Christianae, translated as A Very Fruteful and Pleasant Boke Called the Instruction of a Christen Woman (1523, 1557 ed., London: H. Wykes); Cornelius Agrippa, De Nobilitate et Praecellentia Foeminei Sexus, translated as Female Pre-eminence or the Dignity and Excellency of that Sex above the Male (1529, 1670 ed., London: Million). See, also, Sir Thomas Elyot, The Defence of Good Women (1534, 1545 ed., London: T. Berthelet).

22 For a useful conspectus of the arguments for and against, see B. Castaglione, The Courtier (1527, 1967 ed.) bk. 3 .

23 D.G. Hall (ed.), Tractatus de Legibus et Consuetudinibus Regni Angliae qui Glanvilla Vocatur (1187-89,1965 ed.); S. Thorne (ed.), Bracton on the Laws and customs of England (1968 ed); H.G. Richardson and G.O. Sayle (eds.), Fleta (1955 ed.).

24 Glanvill, id., at p. 77. 
25 id., at p. 59.

26 id., at p. 80.

27 id., at p. 85.

28 F. de Zulueta (ed.), The Institutes of Gaius (1946 ed.) at 5, 'quod omnes homines aut liberi sunt aut servi.

29 Bracton, op. cit., n. 23, vol. 2 at 31 .

30 id., vol. 2 , p. 36.

31 id., vol. 2, p. 105.

32 id., vol. 2, p. 367 ; vol. 3, p. 360 .

33 id., vol. 2, pp. 98-9. M. Astell, Some Reflections upon Marriage (1700, London: J. Nutt) at 389, interestingly picks up on this rule and remarks that 'covenants between husband and wife, like laws in an arbitrary government, are of little force, the will of the sovereign is all in all.'

34 Bracton, id., vol. 2, pp. 54-5.

35 J. Fortescue, De Laudibus Legum Angliae (1468-70, 1737 ed., London: Gosling) chs. xxxixxlv, provides the most considered account of differences between common law and civil law, particularly with regard to legitimacy and guardianship. For later discussion, see C. St. German, Doctor and Student (1528, 1974 ed.).

36 For recent discussions of Roman influence, see F. De Zulueta and P. Stein, The Teaching of Roman Law in England around 1200 (1990); D. Kelley, The Human Measure. Social Thought in the Western Legal Tradition (1990); J. Brundage, Law, Sex and Christian Society in Medievat Europe (1987). The classic study is still J. Selden, Ad Fletam Dissertatio (1617, 1925 ed.).

37 For an extensive discussion, see H. Swinburne, A Brief Treatise of Testaments and Last Wills, very profitable to be understood of all the Subjects of the Realme of England (1590, 1635 ed., London: Society of Stationers) at sig. B i b depicting 'as in a glass those Civill and Ecclesiasticall lawes testementary now in force, and to be observed and executed in the Ecclesiasticall Courts within this realm of England'. J. Godolphin, The Orphan's Legacy or A Testamentary Abridgement in three Parts (1677, London: C. Wilkinson). Generally, see M. Ingram, Church Courts, Sex and Marriage, 1570-1640 (1987).

38 Fortescue, op. cit., n. 9, at p. 192.

39 This issue is debated at some length in T. Wood, Some Thoughts Concerning the Study of the Laws of England (1727 ed., London: J. Stagg). For details, see E. Coke, The First Part of the Institutes of the Laws of England, or, A Commentary on Littleton, not the name of a lawyer only, but of the law itself (1629, London: More).

40 A. Hotman, op. cit., n. 18, pp. 268-9: 'we can say that this rule is a chief work of nature with which she wished to honour France above all other nations of the world ... France has this advantage, that of never having loosened the natural order of their Realm'.

41 Fortescue, op. cit., n. 9, p. 240.

42 id., p. 239.

43 id., p. 224 (decora est facie et venusta aspectu).

44 Maclean, op. cit., n. 5, ch. 7. See, also, D. Curtis and J. Resnik, 'Images of Justice' (1986) 96 Yale Law J. 1727.

45 See Thomas Heywood, Tunaikeion or Nine Bookes of Various History concerninge Women (1624, London: Adam Islip) at 27. See also P. Goodrich, 'Fate as Seduction: The Other Scene of Legal Judgment' in Closure and Critique in Contemporary Legal Theory, ed. A Norrie (1993).

46 Fortescue, op. cit., n. 9, p. 249.

47 id., p. 250 (nam licet nomen justicia generis sit femini . . . ipsa non est femina neque sexus feminini).

48 R. Allestree, The Ladies Calling (1677, London: n.p.) at 68-9: '[of widows] ... the remains of her husband be of three sorts, his body, his memory and his children . . . the more valuable kindness, is that to his memory, endeavouring to embalm that, keep it from perishing, and by this innocent magick . . . she may converse with the dead, represent him so to her own thoughts, that his life may still be repeated to her; and as in a broken mirror the refraction multiplies the Images, so by his dissolution every hour presents distinct ideas of him, so that she sees him the oftener, for his being hid from her eyes'. On memory more generally, see M. Carruthers, The Book of Memory (1990). 
49 Fortescue, op. cit., n. 9, p. 231, citing Isidore of Seville.

50 id., p. 232.

51 id., pp. $233-4$.

52 Num. 27: 4-5, 7-9.

53 Fortescue, op. cit., n. 9, p. 268.

54 id., pp. 251-9.

55 Causa xxxiii, Quaest. 5, ch. Haec Imago.

56 Fortescue, op. cit., n. 9, p. 287.

57 id., at pp. $300-2$.

58 id., at p. 326.

59 J. Perkins, A Profitable Book Treating of the Lawes of England (1532, 1555 ed., London: R. Totel) at s. 86-7.

60 id., at s. 6.

61 id., at s. 8. See, further, H. Swinburne, A Brief Treatise of Testaments and Last Wills, very profitable to be understood of all subjects of this realme of England (1590, 1635 ed., London: Society of Stationers; Godolphin, op. cit., n. 37.

62 Sir Thomas Smith, De Republica Anglorum (1583, London: H. Midleton) at 19.

63 William Rastell, The Expocision of the Termes of the Lawes of Englande (1566, London: R. Totell); J. Cowell, The Interpreter or Book containing the Signification of Words (1607, Cambridge). Both authors list mulier in a technical meaning, as lawfully born rather than bastard: ex muliere as opposed to ex concubina. Both dictionaries nonetheless provide definitions of relevant legal statuses such as patria postestas, coverture or maritagium.

64 Selden, op. cit., n. 9.

65 id., at sig. A 2 a.

66 id., at sig. A 2 a.

67 id., at sig. A 4 a.

68 id., at p. 94.

69 id., at sig. A 3 b.

70 id., at pp. 4-5. For a further and contrary discussion of the three Furies - Alecto (or Luctificia), Tesiphone, and Megaera - see Heywood, op. cit., n. 45, at pp. 47-50, where they are listed as 'infernal Goddesses'. See also J. Selden, De Diis Syris Syntagmata II (1617, London: G. Stansby).

71 Selden, op. cit., n. 9, at p. 5.

72 id., at p. 6. (As, fo: example, in 'fortnight'). The gender of night, of course, has many further significant connotations, some of which can be pursued in Juliana Schiesari, The Gendering of Melancholia: Feminism, Psychoanalysis, and the Symbolics of Loss in Renaissance Literature (1992). See, also, J. Kristeva, Black Sun: Depression and Melancholia (1989); and, most recently, Anne Juranville, La Femme et la Melancholie (1993).

73 Selden, op. cit., n. 9, at pp. 18-19.

74 L. Lloyd, A Briefe Conference of Divers Lawes: Divided into Certaine Regiments $(1600,1602$ ed., London: Creede) at 90. (The source of the argument, ironically, is Aristotle, Politics ch. 7).

75 Selden, op. cit., n. 9, at p. 18.

76 id., at p. 21.

77 See Maclean, op. cit., n. 5, at pp. 29-31, 38-39; the polarities of argument are also analysed in Maclean, op. cit., n. 10, pp. 2-5.

78 Selden, op. cit., n. 9, at pp. 19-21. Lloyd, op. cit., n. 74, at pp. 91-2, offers a similar list.

79 Selden, id., at p. 20.

80 Selden, op. cit., n. 70 , at pp. 124-5.

81 See generally, H.C. Agrippa, Of the Vanitie and Uncertaintie of Artes and Sciences (1575, London: Bynneman).

82 W. Perkins, $A$ Discourse on the Damnable Art of Witchcraft; so farre forth as it is revealed in Scripture, and manifest by true experience (1610, Cambridge: Legge) at fol. $6 \mathrm{a}-\mathrm{b}$.

83 id., at $27-28$. To prove the crime of witchcraft required not simply proof that spells had been cast or imprecations uttered - anyone could do that - but also that the spell or curse had caused harm to, or the death or illness of its intended victim. It is on the question of how such 
proofs should be elicited that Sir Robert Filmer, An Advertisement to the Jury-Men of England Touching Witches (1653, London: Royston) especially at 3-5, challenges Perkins.

84 Selden, op. cit., n. 9, at p. 11. Compare Elyot, op. cit., n. 21, at sig. C iii a-C iv b, who particularly stressed this point. Not only is reason, as an aspect of the soul, by nature both male and female, but prudence, the feminine quality of prudentia or foresight by which the exercise of judgment is made possible, is a female art.

85 Selden, id., at p. 21.

86 John Case, Sphaera Civitatis (1588, Oxford) at 40-1, cited and discussed in Maclean, op. cit., n. 10, at pp. 60-1. On broader issues of interpretation, see I. Maclean, Interpretation and Meaning in the Renaissance: The Case of Law (1992).

87 Knox, op. cit., n. 10, at pp. 40 and 58.

88 Bishop Aylmer, An Harborowe for Faithfull and Trewe Subjectes against the late blowne blaste, concerning the government of women $(1559$, Strasborowe) at fol, $\mathrm{K} 4 \mathrm{~b}-\mathrm{L}$ i a.

89 id., at fol. E 4 b.

90 Leslie, op. cit., n. 13, at fol. 57a-b. His other major statement on women was the more derivative De Illustrium Foeminarum in Republica Administrandi, ac ferendis legibus authoritate (1580 ed., Rheims: J. Fognaeus) which lists erudite women (eruditae mulieres) and urges Queen Mary upon England.

91 id. [1569], at fol. 59a.

92 id., at fol. $75 a-b$.

93 id., at fol. $137 \mathrm{~b}$.

94 W. Heale, An Apologie for Women (1609, Oxford: J. Barnes) at 25-6 (citing Code 9.7).

95 id., at p. 28. W. Perkins, Christian Oeconomie: or a Short Survey of the Right Manner of Erecting and Ordering a Family, according to the Scriptures (1609, 1618 ed., Cambridge: Cantrell Legge) at 688.1 indicates that a wife may leave her husband if he fails to protect her from a stranger or if the husband threatens harm. Sir Thomas Ridley, $A$ View of the Civille and Ecclesiasticall Law $(1607,1676$ ed.) at 82 : 'if any man beat his wife for any other cause, than for which he may be justly severed or divorced from her, he shall for such injury be punished'.

96 Heale, op. cit., n. 94, at p. 46. J. Godolphin, Repertorium Canonicum or, An Abridgement of the Ecclesiastical Laws of this realm consistent with the Temporal $(1678,1687$ ed., London: Atkins) at pp. 507-8, cites Sir Thomas Simmond's Case as well as ecclesiastical doctrine to the effect that correction must be reasonable. Reasonable appeared to mean that the husband could use physical force to correct the wife but only where her offence was one for which the husband could sue for divorce. Interestingly, in light of the earlier discussion, Swinburne, op. cit., n. 37, at p. 300 exempts the Queen from the exclusion of women from making wills without the consent of their husbands.

97 Heale, op. cit., n. 94, at pp. 55-6.

98 id., at pp. 49-50. Compare Calybute Downing, A Discourse of the State Ecclesiastical of this Kingdome, in relation to the Civill $(1586,1632$ ed., Oxford: Turner) at 2-3: 'good manners cause obedience, and religion naturally begets good manners ... for although ill manners are per accidens the cause, or rather the occasion of making good laws, yet they are better in the executing, best when they are obeyed'.

99 On the development of fictions, see Perkins, op. cit., n. 59, at p. 196; T. Wood, An Institute of the Laws of England (1720 ed., Savoy: Sare) at 101-4.

100 See Swinburne, op. cit., n. 37, at pp. 80-4; Godolphin, op. cit., n. 37, at pp. 31-5.

101 See Godolphin, op. cit., n. 96, at p. 507.

102 id., at pp. 515-19. See, for example, Pollard v. Armshaw (1601) 75 ER 1073, or Dorothy Brian v. Cockman (1612) 79 ER 881.

103 A line of legislation which begins with a statute of $1486(3 \mathrm{H}$. VII, c. 2) raising the penalties for carrying a woman away against her will that hath lands or goods.

104 See, for example, Hyatt's Case deciding the right of women to alimony, reported in Godolphin, op. cit., n. 96, at pp. 493-504; also, Wood, op. cit., n. 99, at pp. 105-9.

105 Anon., op. cit., n. 9. Some have attempted to attribute the work to Sir John Doderidge, author of, among other things, The English Lawyer (1629, 1631 ed., London: More) but there 
is no compelling evidence. The work is unique in its scope in English law though it might be noted that there is one German legal treatise that goes some way to achieving the same end: $\mathbf{J}$. Wolff, Discursus: De Foeminarum in jure civili et canonico privilegiis, immunitatibus et praeeminenta (1615, Rostock: M. Saxo). In contemporary terms, the notion of 'Women's Law' has been resurrected in T. Stang-Dahl, Women's Law: An Introduction to Feminist Jurisprudence (1987), who defines the purpose of women's law as being 'to examine and understand how women are considered in law and how the law corresponds to women's reality and needs' (p. 12). See, also, and similarly S. Atkins and B. Hoggett, Women and the Law (1985) at 1: 'we seek to understand how the law has perceived women and responded to their lives.' For a lengthy discussion, see S. Gibson, 'The Structure of the Veil' (1989) 52 Modern Law Rev. 420.

106 See, for example, William Sheppard, The Touchstone of Common Assurances or a plain and familiar treatise, opening the learning of the common assurances or conveyances of the Kingdom (1648, London: W. Lee); Swinburne, op. cit., n. 37, at sig. B i b.

107 Anon., op. cit., n. 9, at p. 2.

108 id., at pp. 403 and 3.

109 id., at p. 3.

110 id., at p. 128.

111 id.

112 id., at p. 129.

113 id., at p. 206.

114 id., at p. 305.

115 id., at p. 232.

116 id., at p. 233.

117 id., at p. 118.

118 id., at p. 52, citing Stamford.

119 id., at p. 206.

120 id., at p. 146. Seé, for an earlier and equally powerful denunciation of this rule, Agrippa, op. cit., n. 21 , at p. 31 .

121 id., at p. 403.

122 id., at pp. 22-3, giving as the reason that she is quickly able domui precesse, vivo subesse.

123 id., at p. 23. For further discussion, see, for example, Wood, op. cit., n. 99, at p. 19

124 Heywood, op. cit., n. 45 , at p. 313.

125 Doderidge, op. cit., n. 105, at p. 15 (defining actus reminiscendi as one part of memory intellective).

126 Pisan, op. cit., n. 21, at sig. C c iii a. See, further, the prescriptions for gynaetopia in Astell, op. cit., n. 33, at pp. 40-5; and, also, the Castle of Fortuna, depicted in Christine de Pisan, Le Livre de la Mutacion de Fortune (1404, 1959 ed., Paris: Picard). For Pisan, justice was anything but blind.

127 As in Leslie, op. cit., n. 90, pp. 23 ff.; see also Daniel Tuvil, Asylum Veneris, or a Sanctuary for Ladies (1616, London: E. Griffin); and for a classic study of philosophical women, see Gilles Ménage, Historia Mulierum Philosopharum (1690, trans. 1984, London: University Press of America). Most influential in England were Agrippa, op. cit., n. 21,; Vives, op. cit., n. 21,; and Elyot, op. cit., n. 21, all of whom list women philosophers amongst other illustrious women.

128 Agrippa, id., respectively at pp. 66, 76 .

129 id., at pp. 10-13.

130 Selden, op. cit., n. 9, at pp. 4-5. For contemporaneous examples, see Sir H. Finch, Law, or, $A$ Discourse Therof in Foure Books (1627, London: Society of Stationers) at 11; W. Fulbeck, Direction or Preparative to the Study of Law (1599, 1829 ed., London: Clarke) at 2-3.

131 A conclusion arrived at by Maclean, op. cit., n. 5, at p. 58 .

132 I have analysed this aspect of justice in P. Goodrich, 'Critical Legal Studies in England: Prospective Histories' (1992) 12 Oxford J. of Legal Studies 195, at 220-5.

133 See Lloyd, op. cit., n. 74, at pp. 130-1, for a direct expression of this view.

134 Of the many contemporary analyses of the face, see E. Levinas, Otherwise than Being (1981) 89-93; J. Derrida, Writing and Difference (1978) at 100 ff.; G. Deleuze and F. Guattari, $A$ 
Thousand Plateaux (1988) at 167-92; A. Jardine, Gynesis: Configurations of Woman and Modernity (1985) at 76-9.

135 Angel Day, The English Secretorie or Methode of Writing of Epistles and Letters (1586, 1607 ed., London: C. Burby) at 121-2.

136 Richard Head, Proteus Redivivus, or the Art of Wheedling or Insinuation (1675, London: W.D.), respectively at pp. 2 and 256 . See also at p. 53: 'the face is the index of the mind; yet experience tells us it is no infallible indicium of the nature or disposition of the person... [for] always to see, is not to know'. See, also, M. Griffith, Bethel or, A Forme for Families (1633, London: Jacob Bloome) at p. 255: 'the visage is for the most part a prognostication of virtue or vice ... Yet thou may'st not trust too much to thine eyes... Some women are like paintedcloth; look on the one side, and thou seest Virgins, Virtues and Queens; but on the other, nothing but patches and rags ....'

137 See, for a particularly strong example, Sir Robert Wiseman, The Law of Laws, or the Excellency of the Civil Law (1664, London: Royston) at pp. 38-45, discussing the failings of argument from precedent. More generally see B. Levack, The Civil Lawyers in England (1973).

138 In terms of the period in question, see the influential St. German, n. 35, at p. 81. See generally T.C. Potts, Conscience in Medieval Philosophy (1980).

139 Sir John Davies, Le Primer Report des Cases en Ley Resolves et Adjudges in Les Courts del Roy en Ireland (1615, Dublin: Franckton) at fol. 4 a.

140 id., at fol. 2 b -3 a.

141 Selden, op. cit., n. 9, at p. xix.

142 John Favour, Antiquitie Triumphing over Noveltie (1619, London: Richard Field), pp. 39-40. (Id est verum quodcumque primum, id est adulteram quodcumque posterius.)

143 Wood, op. cit., n. 99, at p. 17 advocates that the law of persons consider persons in 'their Natural, and in their Relative and Civil capacities'.

144 R. Parker, A Scholasticall Discourse against Symbolizing $(1607$, n.p.) at p. 10.

145 On the 'misteries of Flora', see Lloyd, op. cit., n. 74, at p. 12; and more broadly on flowers, see G. Puttenham, The Arte of English Poesie (1589, London: Field).

146 For striking theological examples, see, particularly, R. Parker, A Scholastical Discourse against Symbolizing (1607, private circulation) at pp. 7-8, 14-17, 19-21; N. Sander, $A$ Treatise of the Images of Christ and of his Saints (1624, Omers: Heigham); H. Hammond, Of Idolatry (1646, Oxford: H. Hall) at pp. 7-9, 12-13. This literature is discussed in greater detail in P. Goodrich, 'Antirrhesis: The Polemical Structure of Common Law Thought' in The Rhetoric of the Law, eds. A. Sarat and T. Kearns (1993).

147 J. Godolphin, op. cit., n. 96, at p. 582.

148 On the universalia of law, see Fortescue, op. cit., n. 35, at pp. 13-14; see also E. Kantorowicz, 'The Sovereignty of the Artist. A note on legal maxims and Renaissance theories of Art' in E. Kantorowicz, Selected Studies (1965).

149 Doderidge, op. cit., n. 105 , at 240.

150 Fortescue, op. cit., n. 35, at pp. 13-14.

151 Fortescue, op. cit., n. 9, at pp. 205-6, "even the judges are bound by their oaths not to render judgment against the laws of the land (leges terrae)', and, similarly, see Selden, op. cit., n. 36, at p. 173.

152 See, for example, William Noy, The Grounds and Maxims of the English Laws (1641, 1757 ed., London: Lintot) at sig. D 3 b: 'every maxim is a sufficient authority to itself; and which is a maxim, and which is not, shall always be determined by the judges, because they are known to none but the learned'. More broadly on this point, see Sir Robert Wiseman, The Law of Laws, or the Excellency of the Civil law above all Humane Laws whatsoever (1664, London: Royston).

153 On which, in philosophical terms, see L. Irigaray, Speculum of the Other Woman (1985) especially 227-40; L. Irigaray, This Sex which is not One (1985) chs. 2 and 6.

154 Jeanne Schroeder, 'Feminism Historicized: Medieval Misogynist Stereotypes in Contemporary Feminist Jurisprudence' (1990) 75 Iowa Law Rev. 1135, particularly at 1143$47,1214-17$, indicating that at certain points in history, the values currently experienced as 'uniquely female' were experienced as 'uniquely male'. 
155 Sir Robert Filmer, op. cit., n. 83, at fol. $\dot{A} 3$ a.

$156 \mathrm{See}$, particularly, in an English context, Agrippa, op. cit., n. 21; Vives, op. cit., n. 21; Elyot, op. cit., n. 21; Leslie, op. cit., n. 90.

157 See Riley, op. cit., n. 5; D. Cornell, Beyond Accomodation: Ethical Feminism, Deconstruction and the Law (1991); J. Butler, Gender Trouble: Feminism and the Subversion of Identity (1990).

158 Digest 1.5.10: 'With whom is a hermaphrodite comparable? I rather think that each one should be ascribed to that sex which is prevalent in his or her make up'.

159 Perkins, op. cit., n. 82, at fol. 6 a-b, 22 a - 27 b. For legislation and writs, see E. Coke, $A$ Book of Entries containing perfect and approved presidents of Courts, Declarations ... and all other matters and proceedings (in effect) concerning the pratick part of the laws of England (1610, 1671 ed., London: Streeter).

160 Respectively, Selden, op. cit., n. 70, at pp. 140-6, and Heywood, op. cit., n. 45, at pp. 2-3.

161 For a legal definition of the gynaeceum, see A. Alciatus, De Verborum Significatione libri Quatuor (1635 ed., Lugudini: S. Gryphius) at 204 and 229.

162 Astell, op. cit., n. 3, at p. 40.

163 id., at p. 48.

164 id., at pp. 81 and 91.

165 Irigaray, op. cit., n. 1, at pp. 103-5. See also Irigaray, op. cit., n. 8, at pp. 210-12.

166 Particularly, C. Gilligan, In a Different Voice (1982). For criticism of that study, see Joan Williams, 'Deconstructing Gender' (1989) 87 Michigan Law Rev. 797. See, also, 'Feminist Discourse, Moral Values and the Law - A Conversation' (1985) 34 Buffalo Law Rev. 11. For a series of stronger arguments in relation to difference and law, see Angela Harris, 'Race and Essentialism in Feminist Legal Theory' (1990) 42 Stanford Law Rev. 581; Patricia Cain, 'Feminist Jurisprudence: Grounding the Theories' (1990) 4 Berkley Women's Law J. 191; K. Crenshaw, 'A Black Feminist Critique of Antidiscrimination Law and Politics' in The Politics of Law, ed. D.Kairys (1990).

167 For philosophical discussion of such rights, see J. Kristeva, 'Women's Time' (1981) 7 Signs 13; C. Clement and H. Cixous, The Newly Born Woman (1986); H. Cixous, Coming to Writing (1991).

168 Irigaray, op. cit., n. 1, at p. 83. For a more detailed discussion, see L. Irigaray, Ethique de la Différence Sexuelle (1984) 114-24.

169 Irigaray [1992], op. cit., n. 8, at p. 205.

170 On the latter right, see also Irigaray [1991], op. cit., n. 8. Also important in the discussion of cultural rights and literary styles was J. Derrida, Spurs: Nietzsche's Styles (1979). In terms of legal feminism, see the discussion in Mary Joe Frug, 'A Postmodern Feminist Legal Manifesto' (1992) 105 Harvard Law Rev. 1045.

171 Irigaray, [1992], op. cit., n. 8, at 207.

172 For an excellent discussion of this practice, see R. Cosin, An Apologie for Sundrie Proceedings by Jurisdiction Ecclesiasticall, of late times by some challenged (1591, London: n.p.) at 51-8. In explicitly feminist terms, see Mary Joe Frug, 'Re-Reading Contracts: A Feminist Analysis of a Contracts Casebook' (1985) 34 Am. University Law Rev. 1065; and 'Rescuing Impossibility Doctrine: A Postmodern Feminist Analysis of Contract Law' (1992) 140 University of Pennsylvania Law Rev. 1029. 